\title{
PENGARUH LAMA PEMANASAN DAN KADAR AIR YANG BERBEDA TERHADAP NILAI GLUKOSA DAN TOTAL KARBOHIDRAT PADA POLLARD
}

\author{
EFFECTS OF DIFFERENT HEATING DURATION AND WATER CONTENT ON \\ GLUCOSE AND TOTAL CARBOHYDRATE IN POLLARD
}

\author{
Akbar, I. A., M. Christiyanto dan C. S. Utama \\ Departemen Peternakan \\ Fakultas Peternakan dan Pertanian Universitas Diponegoro Semarang \\ Email: cahyasetyautama@gmail.com \\ Diterima: 17 Juni 2019, Direvisi: 14 Juli 2019, Disetujui: 31 Juli 2019
}

\begin{abstract}
ABSTRAK
Penelitian bertujuan untuk mengkaji pengaruh lama pemanasan dan kadar air pada nilai glukosa dan total karbohidrat. Rancangan penelitian menggunakan rancangan acak lengkap pola faktorial dengan durasi pemanasan sebagai faktor 1 (T1=15 menit dan $\mathrm{T} 2=30$ menit)-dan kadar air sebagai faktor $2(\mathrm{~A} 1=25 \%, \mathrm{~A} 2=50 \%$, dan $\mathrm{A} 3=75 \%)$ dengan 3 kali ulangan. Parameter yang diamati adalah kadar glukosa dan total karbohidrat. Hasil penelitian pada parameter kadar glukosa, menunjukan bahwa lama pemanasan memberikan pengaruh yang nyata $(p<0,05)$ sedangkan perbedaan level kadar air tidak memberikan pengaruh yang nyata. Pada parameter total karbohidrat, perbedaan level kadar air memberikan pengaruh yang nyata $(\mathrm{p}<0,05)$, sedangkan perbedaan durasi pemanasan tidak memberikan pengaruh nyata. Kesimpulan yang diperoleh dari penelitian adalah perlakuan lama pemanasan dan kadar air, memberikan pengaruh yang nyata berturut-turut pada kadar glukosa dan total karbohidrat. Perlu adanya uji kecernaan lebih lanjut, untuk mendukung hasil dari penelitian ini.
\end{abstract}

Kata kunci : Pollard, kadar glukosa, kadar total karbohidrat, pemanasan

\section{ABSTRACT}

This study aims to determine the effects of different heating duration and water content on glucose and total carbohydrate in pollard. The experimental design in this study used a complete randomized design with two factors, of which are heating duration as the primary factor $(T 1=15$ minutes and $T 2=30$ minutes) water contentas the secondary factor $(A 1=25 \%, A 2=50 \%$, and $A 3=75 \%)$ with 3 replications. On glucose content, the duration ofheat treatment showed significant effect $(p<0,05)$, while difference in water content didnot. On total carbohydrate content, the different water contentshowed significant effect $(p<0,05)$, whereas different heating duration did notshow any significant effect. The research concludes that heating duration and water affects significantly on glucose and total carbohydrate contents, respectively. It is recommended that further research by digestibility analysis is needed to support the result of this research.

Key Words: pollard, glucose content, total carbohydrate content, steaming

\section{PENDAHULUAN}

Pakan merupakan salah satu faktor yang menentukan perkembangan usaha peternakan. Perkembangan industri pakan saat ini cukup pesat, seiring dengan perkembangan industri hewan ternak, 
terutama unggas. Jagung dalam kaitannya dengan hal ini, merupakan bahan pakan yang paling umum digunakan untuk pakan sebagai sumber energi dalam produksi unggas. Jagung selain sebagai pakan ternak, juga bersaing dengan lebutuhan manusia, sehingga harganya relatif lebih mahal apabila dibandingkan dengan pakan sumber energi lainnya. Melihat kondisi ini, penggunaan pakan alternatif jagung dirasa perlu untuk menekan biaya produksi pada peternakan yang mengandalkan jagung sebagai pakan sumber energi utamanya. Salah satu pakan alternatif yang diduga berpotensi sebagai pakan pengganti jagung adalah pollard.

Pollard merupakan hasil samping dari penggilingan gandum menjadi terigu. Kandungan energi pollard hampir menyerupai jagung, namun pollard memiliki keunggulan dalam proteinnya yang lebih tinggi. Energi metabolis pada jagung dan pollard adalah $3350 \mathrm{kkal} / \mathrm{kg}$ dan $3120 \mathrm{kkal} / \mathrm{kg}$, sedangkan kandungan protein pollard yaitu $14,1 \%$ apabila dibandingkan dengan jagung pada kisaran $8,5 \%$ (Tangendjadja et al., 2003). Ketersediaan pollard juga tidak bersaing dengan kebutuhan manusia, sehingga harganya relatif lebih murah. Kelemahan pollard adalah kandungan serat kasarnya yang tinggi, sehingga tidak dapat diberikan secara langsung pada unggas tanpa adanya pengolahan. Serat kasar pada pollard, terdiri atas selulosa, hemiselulosa dan lignin dalam ikatan lignoselulosa (Novitawati, 2009). Selulosa dan hemiselulosa adalah komponen dalam dinding sel yang sulit dicerna oleh hewan monogastrik yang memerlukan proses pengolahan untuk meningkatkan kecernaannya. Pengolahan pollard, dapat dilakukan secara fisik, kimiawi, biologis maupun gabungan.

Proses pemanasan basah (steaming), diduga mampu mengubah struktur fisik dan kimia pollard, sehingga mampu meningkatkan kecernaan dari bahan pakan (Utama el al., 2017; Sulistiyanto et al., 2017). Air dalam perlakuan pemanasan basah pada pati, diduga dapat memicu proses gelatinisasi yang memiliki manfaat untuk mendegradasi karbohidrat di dalam pakan sehingga dapat meningkatkan kecernaanya. Kadar glukosa diharapkan akan meningkat dengan perlakuan ini sedangkan kadar karbohidrat total akan menurun yang menandakan terjadinya konversi pati menjadi glukosa.

Tujuan dari penelitian adalah untuk mengkaji pengaruh pengolahan bahan pakan metode pemanasan basah dengan perlakuan perbedaan lama pemanasan dan level kadar air terhadap kadar glukosa dan total karbohidrat pollard. Adapun hasil dari penelitian diharapkan dapat memberikan informasi dan inovasi baru dalam peningkatan mutu bahan pakan melalui proses pengolahan secara pemanasan basah.

\section{MATERI DAN METODE}

Bahan dan alat penelitian yang digunakan adalah pollard, akuades dan autoclave. Penambahan kadar air dilakukan pada pollard dengan level 25, 50 dan $75 \%$. Pollard yang telah diberi perlakuan kemudian dipanaskan dalam autoclave pada suhu $121^{\circ} \mathrm{C}$, dengan durasi selama 15 dan 30 menit. Pollard dikeringkan di dalam oven pada suhu $70^{\circ}$ $\mathrm{C}$ selama 8 jam untuk menghilangkan kadar airnya. Kadar glukosa dan total karbohidrat kemudian dianalisis berdasarkan metode Luff-Schoorl (GAFTA, 2014). Data kemudian diuji statistik menggunakan rancangan acak lengkap pola faktorial 3x2 dengan 3 kali ulangan. Pengujian dilakukan lebih lanjut menggunakan uji Duncan pada taraf signifikansi 95\% (Steel dan Torrie, 1993). 
HASIL DAN PEMBAHASAN

Kadar Glukosa

Tabel 1.

Hasil Kadar Glukosa yang Diberi Perlakuan Lama Pemanasan dan Kadar Air yang Berbeda

\begin{tabular}{cccc}
\hline \hline Kadar Air (\%) & \multicolumn{2}{c}{ Durasi (menit) } & Rerata \\
\hline \hline & 15 & 30 & \\
\hline 25 & $110,25^{\mathrm{a}}$ & $92,45^{\mathrm{b}}$ & 101,35 \\
50 & $109,01^{\mathrm{a}}$ & $93,51^{\mathrm{b}}$ & 101,26 \\
75 & $107,77^{\mathrm{a}}$ & $94,57^{\mathrm{b}}$ & 101,18 \\
\hline Rerata & 108,72 & 93,09 & \\
\hline
\end{tabular}

Keterangan:Superskrip yang berbeda pada baris yang sama menunjukkan perbedaan yang nyata $(\mathrm{p}<0,05 \%)$

Perlakuan lama pemanasan memberikan pengaruh yang nyata $(\mathrm{p}<0,05)$ pada glukosa (Tabel 1). Hal ini diduga karena proses pemanasan yang terlalu lama sehingga terjadi kerusakan pada molekul glukosa yang mendekati suhu $140^{\circ} \mathrm{C}$ (Woo et al., 2015). Smith (1985), menyatakan bahwa beberapa manfaaat dari gelatinisasi antara lain dapat meningkatkan kecepatan reaksi enzimatis untuk memecah ikatan pati menjadi bentuk yang lebih sederhana yang mudah larut serta meningkatkan konversi dan kecernaan dari pakan. Durasi dan level kadar air optimum gelatinisasi juga berbeda pada setiap bahan pakan dan akan membentuk tekstur jel yang semakin kental pada pemanasan yang semakin lama. Haryadi (1984) berpendapat bahwa suhu pemanasan yang semakin tinggi akan meningkatkan konsentrasi pati tergelatinisasi yang semakin tinggi sehingga pasta yang terbentuk semakin tebal.

Gelatinisasi merupakan membengkaknya partikel pati di dalam bahan karena masuknya air ke dalam partikel pati dan bersifat irreversibel (Winarno, 2002). Hal ini sesuai dengan pernyataan Aryanti et al. (2017), bahwa gelatinisasi merupakan proses pembengkakan granula pati, sehingga tidak dapat kembali pada bentuk semula. Proses masuknya air inidisebabkan karena pecahnya dinding molekul pati melalui adanya air dalam proses pemanasan. Gelatinisasi dan sifat pembengkakan dari pati sebagian dikontrol oleh struktur amilopektin, komposisi pati, dan bentuk granulanya (Immaningsih, 2012). Sulistiyanto et al. (2017), menyatakan bahwa air merupakan sumber penghantar panas sehingga mampu mempengaruhi struktur karbohidrat yang terkandung dalam pollard gandum melalui proses gelatinisasi.

Granula pati yang memiliki kandungan amilopektin lebih tinggi akan membengkak lebih besar dibandingkan dengan yang memiliki kandungan yang lebih rendah. Adapun efek dari reaksi ini menyebabkan perubahan pada tekstur bahan menjadi lebih kenyal. Hal ini disebabkan air yang masuk ke dalam granula pati menyebabkan pembentukan tekstur seperti jel. Uhi (2006), juga menyatakan bahwa masuknya air ke dalam granula pati menyebabkan struktur seperti pasta pada pati. Berdasarkan hasil penelitian, menunjukkan bahwa kadar glukosa tertinggi diperoleh pada perlakuan kadar air $25 \%$ dengan durasi pemanasan 15 menit. 


\section{Kadar Total Karbohidat}

Tabel 2.

Hasil Kadar Total Karbohidrat yang Diberi Perlakuan Lama Pemanasan dan Kadar Air yang Berbeda

\begin{tabular}{cccc}
\hline \hline & \multicolumn{2}{c}{ Durasi } & \multirow{2}{*}{ Rerata } \\
\cline { 2 - 3 } Kadar Air $(\%)$ & 15 menit & 30 menit & \\
\hline 25 & $4691,77^{\mathrm{a}}$ & $5506,94^{\mathrm{a}}$ & 5099,35 \\
50 & $6040,64^{\mathrm{a}}$ & $5862,00^{\mathrm{a}}$ & 5951,32 \\
75 & $6538,67^{\mathrm{b}}$ & $6836,79^{\mathrm{b}}$ & 6687,73 \\
\hline Rerata & 5757,02 & 6068,57 &
\end{tabular}

Keterangan:Superskrip yang berbeda pada kolom yang sama menunjukkan perbedaan yang nyata $(\mathrm{p}<0,05 \%)$

Hasil penelitian menunjukan adanya peningkatan pada nilai total karbohidrat pada pollard yang diberikan perlakuan. Dapat dilihat pada Tabel 2., perbedaan level kadar air berpengaruh nyata $(\mathrm{p}<0,05)$ pada nilai total karbohidrat. Karbohidrat pada pollard, terdiri atas karbohidrat kompleks sepert selulosa, hemiselulosa dan pati, serta karbohidrat sederhana seperti glukosa. Hal ini sesuai dengan pernyataan Siregar (2014), bahwa karbohidrat terdiri atas karbohidrat sederhana (seperti glukosa dan fruktosa) dan karbohidrat kompleks yang terdiri atas polisakarida (dekstrin, glikogen dan pati).

Naiknya nilai total karbohidrat terbaca pada hasil penelitian, diduga disebabkan karena membengkaknya molekul granula pati. Pembengkakan granula pati oleh air, menyebabkan berat molekul pati yang naik, sehingga mengakibatkan kadar total karbohidrat terbaca pada tabel mengalami peningkatan. Hal ini sesuai dengan pendapat Haryadi (1984) bahwa suhu pemanasan yang semakin tinggi, maka akan meningkatkan konsentrasi pati tergelatinisasi yang semakin tinggi, sehingga pasta yang terbentuk semakin tebal.

Peningkatan total karbohidrat juga berkorelasi positif dengan rasio kadar air dalam bahan. Hal ini bertolak belakang dengan dugaan awal bahwa semakin tinggi kadar air, akan semakin tinggi proses konversi karbohidrat kompleks menjadi glukosa. Hal ini disebabkan oleh arah reaksi yang diharapkan, lebih dominan pada reaksi gelatinisasi. Pada proses gelatinisasi, karbohidrat yang berperan adalah pati.

Menurut Faizah (2012), pollard memiliki kandungan pati yang tinggi yang mengandung amilosa dan amilopektin yang tinggi yang dapat menyebabkan gelatinisasi. Kadar air diduga menjadi penyebab meningkatnya persentase nilai total karbohidrat di dalam pollard. Hal ini dikarenakan karena membengkaknya granula pati oleh air pada saat pemanasan, sehingga meningkatkan bobot dari pati yang akhirnya meningkatkan kadar total karbohidratnya. Hal ini sesua dengan pendapat Palguna et al. (2013), bahwa rasio kadar air dalam pemasakan berkorelasi positif terhadap nilai gelatinisasi pati. Hasil penelitian menunjukkan bahwa perlakuan tertinggi adalah pada pemanasan dengan lama 30 menit dan level kadar air 75\%, yang ditandai dengan kadar karbohidrat paling tinggi.

\section{KESIMPULAN DAN SARAN}

Berdasarkan hasil penelitian dapat disimpulkan bahwa perlakuan durasi pemanasan yang berbeda pada saat pemanasan berpengaruh pada kadar 
glukosa pollard. Kombinasi perlakuan optimum yang menghasilkan konversi pati menkadi glukosa tertinggi adalah pada perlakuan pemanasan selama 15 menit dengan penambahan air $25 \%$, sedangkan nilai total karbohidrat tertinggi diperoleh pada perlakuan pemanasan selama 30 menit dengan penambahan air $75 \%$.
Penelitian selanjutnya diperlukan untuk mengukur digestabilitas / kecernaan bahan yang diolah dengan cara yang sama untuk pakan ternak secara langsung. 


\section{DAFTAR PUSTAKA}

Agustini, L. dan L. Efiyanti. 2015. Pengaruh perlakuan delignifikasi terhadap hidrolisis selulosa dan produksi bioetanol dari limbah berlignoselulosa. Jurnal Penelitian Hasil Hutan 33 (1): 69 - 80

Aryanti, N., Y. A. Kusumastuti dan W. Rahmawati. 2017. Pati talas (Colocasia esculenta (L.) Schoott) sebagai alternatif sumber pati industri. Jurnal Momentum 13 (1): $46-52$

Crawford, R. L. Lignin Biodegradation and Transformation. John Wiley and Sons, New York.

Faizah, S. 2012. Kadar gula pereduksi an protein terlarut dalam pollard hasil pertumbuhan Aspergillus niger dan Rhizopus oryzae. Fakultas Matematika dan Ilmu Pengetahuan Alam, Universitas Jember. (Skripsi)

GAFTA, 2014. Determine of sugar: LuffSchoorl based method. The Grain and Feed Intake Association Ltd., London.

Hariyadi, P. 1984. Mempelajari Kinetika Gelatinisasi Sagu (Metroxylon sp). Fakultas Teknologi Pertanian, Institut Pertanian Bogor. (Skripsi)

Haryanti, P., R. Setyawati dan Rumpuko Wicaksono. 2014. Pengaruh suhu dan lama pemanasan sespensi pati serta konsentrasi butanol terhadap karakteristik fisikokimia pati tinggi amilosa dan tapioka. Agritech 34 (3): $308-315$.

Hidayat, M. R. 2013. Teknologi pretreatment bahan lignoselulosa dalam proses produksi bioetanol. Biopropal Industri 4 (1): 33 - 48

Immaningsih, N. 2012. Profil gelatinisasi beberapa formulasi tepung-tepungan untuk pendugaan sifat pemasakan (gelatinisation profile of severat flour formulations for estimating cooking behaviour). Panel Gizi Makan 35 (1): 13 - 22

Karim, I. I. 2014. Kandungan ADF, NDF, Selulosa dan Lignin Silase Pakan Kompit Berbahan Dasar Jerami Padi dan Beberapa Level Biomassa Murbei (Morus alba). Fakultas Peternakan, Universitas Hasanudin, Makassar. (Skripsi)

Ketaren, P. P. 2010. Kebutuhan gizi ternak unggas di Indonesia. Wartazoa 20 (4): $172-178$

Noviawati, R. T. 2009. Pemanfaatan Pollard (Limbah Penggilingan Gandum) untuk Produksi Pemanis Xilitol. Fakultas Matematika dan Ilmu pengetahuan Alam, Departemen Kimia, Universitas Indonesia, Jakarta.

Palguna, I. G. P. A., Sugiyono dan B., Haryanto. 2013. Optimasi rasio pati terhadap air dan suhu untuk pembentukan pati resisten tipe III pada pati sagu (Metroxylon sagu) (Ratio optimization of starch to water gelatinization temperature tp produce resistant starch type III of sago starch (Metroxylon sagu)). Jurnal Pangan 22 (3): 253 - 262

Siregar, N. 2014. Karbohidrat. Jurnal Ilmu Keolahragaan 13 (2): 38 - 44

Smith, P.S. 1982. Starch Derivatives and Their Use in Foods. In: Lineback, D.R. dan Paschall, G.E. 1982. Food Carbohydrates. Avi Publishing Company. Inc. Westport. Connecticut

Steel, R. G. D. dan J. H. Torrie. 1993. Prinsip dan Prosedur Statistik: Suatu Pendekatan Biometrik. Diterjemahkan oleh Bambang Sumantri. Cetakan ke- 4. Gramedia Pustaka Utama, Jakarta

Sulistiyanto, B., S. Kismiati dan C. S. Utama. 2017. Perubahan kadar rafinosa, glukosa, manosa, arabinosa dan sukrosa wheat 
pollard akibat lama steam dan penambahan ari yang berbeda. Jurnal Litbang Provinsi Jawa Tengah 15 (2): 161 - 169

Sumardjo, D. 2008. Pengantar Kimia: Buku Panduan Kuliah Mahasiswa Kedokteran dan Program Strata I Fakultas Bioeksakta. EGC, Jakarta.

Sunarya, Y dan A. Setiabudi. 2007. Mudah dan Aktif Belajar Kimia. PT. Setia Purna Inves, Bandung.

Susanti, S. dan E Marhaeniyanto. 2007. Jurnal Protein 15 (2): 141 - 147

Sutikno, Marniza dan M. F. Yanti. 2015. Pengaruh perlakuan awal basa dan asam terhadap kadar gula reduksi tandan kosong kelapa sawit. Jurnal Teknologi Industri dan hasil Pertanian 20 (1): 1 - 10

Tangendjadja, B., Y. Yusdja dan N. Ilham. 2003. Analisis ekonomi permintaan jagung untuk pakan. Badan Litbang Pertanian, Jakarta.

Uhi, T. H. 2006. Pemanfaatan gelatin tepung sagu (Metroxylon sago) sebagai bahan pakan ternak ruminansia (utilization of sago (Metroxylon sago) gelatin as feed ruminant). Jurnal Ilmu Ternak 6 (2): $108-111$
Utama, C.S., B. Sulistiyanto, and S. Kismiati. 2017. The effects of water addition and steaming duration on starch composition of wheat pollard. Reaktor. 17(4): 220-224.

Wahyudi, J., W. A. Wibowo., Y. A. Rais dan A. Kusumawardani. 2011. Pengaruh suhu terhadap kadar glukosa terbentuk dan konstanta kecepatan reaksi pada hidrolisa kulit pisang. Prosiding Seminar Nasional Teknil Kimia Kejuangan. Yogyakarta, 22 Februari 2011.

Wardani, W. W., N. Ramli dan W. Hermana. 2004. Ketersediaan energi ransum yang mengandung wheat pollard hasil olahan enzim cairan rumen yang diproses secara steam pelleting pada ayam broiler. Jurnal Media Peternakan 27 (3): 123 - 128

Winarno, F. G. 2002. Kimia Pangan dan Gizi. PT Gramedia, Jakarta

Woo, K. S., H. Y. Kim, I. G. Hwang, S. H. Lee and H. S. Jeong. 2015. Characteristics of the thermal degradation of glucose and maltose solutions. Preventive Nutrition and Food Science Journal 20 (2): 102 109 